\title{
Low rate of recurrence of Helicobacter Pylori infection in spite of high clarithromycin resistance in Pakistan
}

\author{
Javed Yakoob', Shahab Abid ${ }^{1 *}$, Wasim Jafri ${ }^{1}$, Zaigham Abbas' ${ }^{1}$, Khalid Mumtaz ${ }^{1}$, Saeed Hamid ${ }^{1}$ \\ and Rashida Ahmed ${ }^{2}$
}

\begin{abstract}
Background: The aim was to investigate the reinfection rate of $\mathrm{H}$. pylori during a follow-up period of 12 months in adults who had undergone eradication therapy.

Methods: One hundred-twenty patients; 116 with gastritis, 3 with duodenal ulcer and 1 gastric ulcer, were studied. Their mean age was $41 \pm 13$ years (range 18-77) and male: female ratio of 2:1. H. pylori were cultured and antibiotic sensitivity was determined by Epsilometer test (E-test) for clarithromycin (CLR) and amoxicillin (AMX). Primers of urease C gene of $\mathrm{H}$. pylori and Sau-3 and Hha I restriction enzymes were used for polymerase chain reaction-restriction fragment length polymorphism analysis (PCR-RFLP). ${ }^{14} \mathrm{C}$ urea breath test $\left({ }^{14} \mathrm{C}-\mathrm{UBT}\right)$ was performed 4 weeks after the eradication therapy. The successfully treated patients were observed for 12 months with ${ }^{14} \mathrm{C}$-UBT to assess $\mathrm{H}$. pylori status. If ${ }^{14} \mathrm{C}$-UBT was negative, it was repeated after every 12 weeks. If ${ }^{14} \mathrm{C}$-UBT was positive, endoscopy was repeated with biopsies.
\end{abstract}

Result: The eradication therapy was successful in 102(85\%) patients. Out of forty-seven H. pylori isolates cultured, clarithromycin sensitivity was present in 30(64\%) and amoxicillin in $45(98 \%)$, respectively. Follow-up ${ }^{14} \mathrm{C}$-urea breath tests of all 102 patients who eradicated $H$. pylori remained negative up to 9 months. However, in 6 patients, the ${ }^{14} \mathrm{C}$-UBT confirmed recurrence at 12 months. The recurrence rate was $6 \%$.

Conclusion: A low rate of recurrence of $H$. pylori infection was found in patients with dyspeptic symptoms. H. pylori isolates demonstrated a high invitro clarithromycin resistance.

Keywords: Helicobacter pylori, Clarithromycin resistance, Recurrence, Nonulcer dyspepsia

\section{Background}

Helicobacter pylori (H. pylori) is a Gram negative microorganism that has been categorized as a class I carcinogen [1]. It is associated with gastritis, gastric and duodenal ulcers, gastric adenocarcinoma, and mucosa-associated lymphoid tissue lymphoma [2]. Long term chronic gastritis associated with $H$. pylori is known to progress to glandular atrophy and intestinal metaplasia (IM) over a period of 12 years [3]. Helicobacter pylori gastritis may lead to multifocal atrophy and IM, gradually expanding from the antrum to the body [3]. A long term study with five year

\footnotetext{
*Correspondence: shahab.abid@aku.edu

'Department of Medicine, Aga Khan University, Stadium Road, Karachi 74800, Pakistan

Full list of author information is available at the end of the article
}

follow up from China have reported no change in the degree of intestinal metaplasia (IM) and atrophy after successful eradication [3]. In other long term randomized controlled trials there was a significant regression of preneoplastic lesions such as atrophy and IM among those who had cleared the infection after five to six years of follow up $[4,5]$. A definite cure of peptic ulcer disease and prevention of ulcer complications, as well as cure of mucosa-associated lymphoid tissue (MALT) lymphoma is dependent on successful eradication of $H$. pylori.

Recurrence of $H$. pylori after a successful eradication is rare in developed countries and more frequent in developing countries [6]. Recrudescence is recolonization of the same strain while reinfection is colonization with a new strain. Reinfection is considered to be more likely

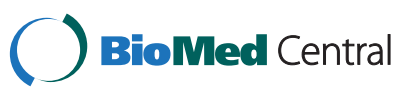


to be responsible for most of the cases [6]. This differentiation is difficult and requires utilization of molecular fingerprinting techniques to confirm that the identified bacteria, before and after therapy, are genetically identical [7]. Recrudescence results from treatment failure while reinfection is considered a problem of heavy $H$. pylori contamination of the environment, drinking water, institutionalized patients, medical personnel or family members, especially in developing countries [6]. In developing countries, $H$. pylori infection is widespread.

Regional studies available from Bangladesh, India and Iran have shown varied recurrence rates [8-10]. In a recent study in Karachi in apparently healthy children, H. pylori seroprevalence in children aged 11-15 years was 54\% [11]. H. pylori seropositivity increased with age and in lowmiddle socioeconomic status [11]. However, local studies addressing the issue of recurrence of $H$. pylori are not available. In this study we investigated the recurrence rate of $H$. pylori during a follow-up period of 12 months in adults who had undergone eradication therapy.

\section{Methods}

\section{Patients}

One hundred-twenty consecutive patients with dyspepsia attending the endoscopy suite of gastroenterology section of Aga Khan University Hospital were enrolled from April 2008-June 2010. There were eighty males and forty females (age range 17-80 years, mean age 41 \pm 13 years; Table 1). An informed consent was taken from all patients and the Aga Khan University ethics review committee approved the study. Only those who were willing to comply with the follow-up schedule and gave informed consent were enrolled in the study. Pregnant and lactating women, patients with esophageal or gastric tumors and patients with liver cirrhosis and esophageal varices were excluded. In addition, those who had received antisecretory drugs, antibiotics, nonsteroidal anti-inflammatory drugs, corticosteroids or bismuthcontaining drugs during the preceding 8 weeks were also excluded. All the patients were native residents of the city. Endoscopic examination was conducted using Olympus video endoscopes (Olympus Tokyo, Japan), and the presence of lesions in the esophageal and gastroduodenal mucosa was noted. Gastric biopsy specimens were obtained three each from the antrum and corpus for rapid urease test (RUT), histology, culture and PCR for $H$. pylori urease $\mathrm{C}$ gene. The biopsies from the antrum were obtained $2-3 \mathrm{~cm}$ from the pylorus, and from the body, midway between the antral-body junction and the cardia. Patients who were positive for H. pylori infection by means of ${ }^{14} \mathrm{C}$-UBT with RUT or histology received treatment comprising of a proton pump inhibitor (esomeprazole) $20 \mathrm{mg}$ BD (twice a day) for 10 days and clarithromycin $500 \mathrm{mg} \mathrm{BD}$ and amoxicillin $500 \mathrm{mg}$ BD
Table 1 Patients characteristics

\begin{tabular}{|c|c|}
\hline Age (years) & \\
\hline Mean \pm SD & $41 \pm 13$ \\
\hline Range & $18-77$ \\
\hline \multicolumn{2}{|l|}{ Gender } \\
\hline Male & $80(67)^{*}$ \\
\hline Female & $40(33)$ \\
\hline \multicolumn{2}{|l|}{ Diagnosis } \\
\hline Gastritis & $116(97)$ \\
\hline Gastric ulcer & $1(1)$ \\
\hline Duodenal ulcer & $3(2)$ \\
\hline \multicolumn{2}{|l|}{ Histology } \\
\hline Grade 1 & $61(51)$ \\
\hline Grade 2 & $54(45)$ \\
\hline Grade 3 & $5(4)$ \\
\hline Antibiotic susceptibility pattern & $\mathrm{n}=47$ \\
\hline \multicolumn{2}{|l|}{ Clarithromycin } \\
\hline Sensitive & $30(64)$ \\
\hline Resistance & 17(36) \\
\hline \multicolumn{2}{|l|}{ Amoxicillin } \\
\hline Sensitive & $45(96)$ \\
\hline Resistance & 2(4) \\
\hline \multicolumn{2}{|c|}{ H. pylori DNA fingerprint (PCR-RFLP) } \\
\hline Same on both sides & $102(85)$ \\
\hline Different on both sides & 18(15) \\
\hline
\end{tabular}

for 7 days. Two weeks after completion of treatment, ${ }^{14} \mathrm{C}$-UBT was performed to document eradication of $H$. pylori infection. Patients with positive ${ }^{14} \mathrm{C}$-UBT were excluded from the study while those with negative were followed up every 3 months by a ${ }^{14} \mathrm{C}$-UBT for 12 months until it tested positive and was followed by endoscopy and biopsy.

\section{Sample size}

The required sample size is 103 individuals, calculated on the basis of an estimated prevalence of reinfection of $13 \%$ and bound on error of estimation specified to be at the most .065 (6.5\%) and a confidence level of 95\% [8].

\section{Rapid urease test}

The tissue specimens were used for the RUT (Pronto dry, Medical Instrument Corp, France) consisting of a dry filter paper enriched with urea, phenol red (a pH indicator), buffers and a bacteriostatic agent in a sealed plastic slide [12]. H. pylori urease enzyme present in the biopsy tissue sample decomposed urea to cause a $\mathrm{pH}$ rise that changed color of the dot from yellow to a bright magenta. Pronto Dry results were read in 30 minutes 
and one hour. The color change from yellow to pink was considered a positive result and no color change as negative for Pronto Dry.

\section{Histological analysis}

Formalin-fixed and paraffin-embedded gastric biopsy specimens were routinely processed. Gastritis activity was graded on a four-point scale of none (grade 0), mild (grade 1), moderate (grade 2), and severe (grade 3) according to the guidelines of the Sydney system [13]. The presence of $H$. pylori was assessed on modified Giemsa-stained sections.

\section{${ }^{14} \mathrm{C}$ - Urea breath test}

Patients swallowed $37 \mathrm{kBq}(1 \mu \mathrm{Ci})$ of an encapsulated form of 14C-urea/citric acid composition (Helicap, Noster System AB, Sweden) with water after endoscopy [14]. Breath samples were collected with a special dry cartridge system (Heliprobe Breath Card, Noster System AB, Sweden) after $10 \mathrm{~min}$. Patients exhaled gently into the cartridge mouthpiece until the indicator membrane changed in color from orange to yellow. Breath card was inserted into a $\beta$-scintillation counter (Heliprobe-analyser, Noster System AB Stockholm, Sweden) and activity was counted for $250 \mathrm{~s}$. Results were expressed both as counts per minute (HCPM) and as grade (0: not infected, $\mathrm{CPM}<$ 25; 1: equivocal, CPM 25-50; 2: infected, $C P M>50$ ), which was suggested by the manufacturer according to the counts obtained from the cartridges. Grades 0 and 1 were considered negative for the detection of $H$. pylori. In a previous study the accuracy of ${ }^{14} \mathrm{C}$-UBT was compared to histology and RUT. Accuracy of ${ }^{14} \mathrm{C}$-UBT was $93 \%$ in comparison with histology while its positive and negative predictive values were $97 \%$ and $84 \%$, respectively [14]. Comparison of ${ }^{14} \mathrm{C}-\mathrm{UBT}$ with RUT gives an accuracy of $96 \%$, with positive and negative predictive values of $95 \%$ and $97 \%$, respectively [14].

\section{Culture and identification of $\mathrm{H}$. pylori}

The specimens were transported immediately in sterile phosphate buffered saline to isolate $H$. pylori. Thus, within three hours of collection each specimen was homogenized and the resulting suspension was inoculated onto Columbia Blood Agar (Oxoid) medium and Dents supplement (containing vancomycin, trimethoprim and polymyxin) and incubated at $37^{\circ} \mathrm{C}$ under microaerophilic conditions for 4-7 days. Plates were then examined for bacterial growth and typical colonies were selected for identification. The identity of $H$. pylori was confirmed by Gram stain, urease and catalase test. One half of the homogenate was used for culture, and the other half was kept at $-80^{\circ} \mathrm{C}$ for future DNA extraction. H. pylori isolates were defined as gram-negative spiral-shaped bacilli that were catalase positive and rapidly (less than $1 \mathrm{~h}$ ) urease positive. H. pylori NCTC 11637 (type strain) was used as a positive control for the culture conditions and identification tests.

\section{Antibiotic susceptibility testing}

Antibiotic susceptibility was determined on Mueller Hinton agar (Oxoid, UK) containing 10\% defibrinated sheep blood and a cell suspension calibrated at 3 McFarland units by the Epsilometer (E-test) using clarithromycin and amoxicillin E-test strips (AB Biodisk, Solna, Sweden). Plates were read after 3 days of incubation at $37^{\circ} \mathrm{C}$. The tests were carried out according to the manufacturer's instructions. H. pylori NCTC 11637 was used as a sensitive control.

\section{Extraction of genomic DNA}

DNA was extracted from gastric tissue as described before [15]. Samples were stored at $-20^{\circ} \mathrm{C}$ before PCR amplification was performed. DNA content and purity was determined by measuring the absorbance at $260 \mathrm{~nm}$ and $280 \mathrm{~nm}$ using a spectrophotometer (Beckman DU600, USA).

\section{PCR amplification for $\mathrm{H}$. pylori ure $\mathrm{C}$ gene}

PCR was performed using extracted DNA as the template and urease gene $C$ for primers. Forward primer (5'TGGGACTGATGGCGTGAGGG-3') and reverse primer (5'-AAGGGCGTTTTTAGATTTTT-3') were prepared from the urease gene sequence according to the report of Labigne et al. [16]. PCR amplification was carried out in a total volume of $50 \mu \mathrm{L}$ containing $2 \mu \mathrm{L}$ of $2 \mathrm{mmol} / \mathrm{L}$ dNTPs, $1 \mu \mathrm{L}$ containing 50 pmol of primer $1,1 \mu \mathrm{L}$ containing 50 pmol of primer 2 (synthesized by ABI Automatic synthesizer), 1 unit of Taq DNA polymerase (Promega), $5 \mu \mathrm{L}$ of $10 \times \mathrm{PCR}$ reaction buffer, $3 \mathrm{mmol} / \mathrm{L}$ of $\mathrm{MgCl}_{2}, 2 \mu \mathrm{L}$ of DNA template containing $0.5 \mathrm{ng}$ of extracted DNA and total volume rounded to $50 \mu \mathrm{L}$ by double distilled water. The reaction was carried out in a Perkin Elmer 9700 thermal cycler. The amplification cycle consisted of an initial denaturation of target DNA at $95^{\circ} \mathrm{C}$ for $5 \mathrm{~min}$ and then denaturation at $94^{\circ} \mathrm{C}$ for $1 \mathrm{~min}$, primer annealing at $56^{\circ} \mathrm{C}$ for $1 \mathrm{~min}$ and extension at $72^{\circ} \mathrm{C}$ for $1 \mathrm{~min}$. The final cycle included an extension step for $5 \mathrm{~min}$ at $72^{\circ} \mathrm{C}$ to ensure full extension of the product. Samples were amplified through 35 consecutive cycles. Negative reagent control reactions were performed with each batch of amplifications, consisting of tubes containing distilled water in place of the DNA samples. Five $\mu \mathrm{L}$ of PCR product was electrophoresed on a $1.5 \%$ agarose gel to ensure homogeneity and yield. PCR amplification resulted in a homogeneous DNA fragment of the expected size of $820 \mathrm{bp}$ for ure $\mathrm{C}$ gene. 


\section{PCR-RFLP}

The amplified products obtained by PCR were subjected to restriction endonuclease digestion for 2 hours at $37^{\circ} \mathrm{C}$ in 20 microliter $(\mu \mathrm{l})$ volume, as recommended [17]. The digested samples were analyzed by agarose gel (3\%, wt/ volume) electrophoresis. Restriction enzyme Sau-3 (5U) and Hha I (5 U), (New England Biolabs) were used on the basis of sequence data available for this amplified product. The restriction enzyme HhaI recognized on the 820-bp UreC gene amplified PCR product restriction site 5 '...GCG ${ }^{\downarrow} \mathrm{C} \ldots 3$ ' giving 2 fragments varying in size from 100 bps to $550 \mathrm{bps}$ and showing 4 band patterns while restriction enzyme Sau3A1 recognized site 5 '... GATC..3'giving 3 fragments ranging in size from 50 bps to 600 bps having 7 bands patterns, respectively. RFLP analysis by HhaI and Sau 3A together generated eleven distinguishable digestion patterns. Small variations ( $<10 \mathrm{bps})$ in the size of the restriction fragments were not considered a different pattern. In case of an identical restriction pattern from antrum and body, the patient was considered to have an infection by the same $H$. pylori strain while by restriction fragments that exceeded amplified fragment size and yielded different restriction fragments, patient was considered to be infected by different $H$. pylori strains.

\section{Statistical assessment}

The statistical package for social science SPSS (Release 16, standard version, copyright (c) SPSS; 1989-2007) was used for data analysis. The descriptive analysis was done for demographic and clinical features. Results were presented as mean \pm standard deviation for quantitative variables and number (percentage) for qualitative variables. Differences in proportion were assessed by using Pearson Chi square, Fisher exact or likelihood ratio test where appropriate. $\mathrm{P}$ value less than 0.05 was considered as statistically significant, all $p$ values were two sided.

\section{Results}

All one hundred-twenty patients with $H$. pylori infection had positive ${ }^{14} \mathrm{C}$-UBT. Rapid urease test was positive in 116 out of 120 (97\%) and negative in 4 out of 120 (3\%). Histology demonstrated $H$. pylori associated gastritis in 114 out of 120 (95\%) and nonspecific gastritis in 6(5\%).
Four patients negative by RUT had positive C-14 UBT and $H$. pylori positive gastritis while six patients demonstrating nonspecific gastritis had positive ${ }^{14} \mathrm{C}-\mathrm{UBT}$ and RUT. The distribution of negative RUT ( $p=1$ and $p=$ $0.69)$ and histology $(p=0.600$ and $p=0.095)$ for $H$. pylori infection were not associated with age and gender.

\section{Recurrence of $\mathrm{H}$. pylori after successful eradication}

One hundred-twenty patients had positive ${ }^{14} \mathrm{C}$-UBTs on initial visit. After treatment 18 out of 120 (15\%) were still positive and were excluded from the study. At 12 months, the ${ }^{14} \mathrm{C}$-UBT confirmed recurrence in six patients. No statistically significant difference was seen for sex (Fisher's Exact Test $p=1)$ or age ( $p=0.697)$. All cases of recurrence were from the local population. They were diagnosed as having non-ulcer dyspepsia (NUD) with evidence of endoscopic gastritis and mild to moderate chronic active gastritis on histology (Table 2). In the follow-up period, none of the 3(3\%) duodenal ulcer patients with successful eradication had any symptoms suggesting ulcer though we did not do repeat endoscopy in these patients.

\section{PCR-based RFLP analysis}

In 103 of 120 isolates (86\%), we demonstrated the same DNA fingerprint from isolates from the antrum and mid-body gastric sites, and the patterns were different in 17(14\%). Six of the 102 patients had recurrence of $H$. pylori during the follow-up period after treatment. Five of these 6 patients were previously documented to have colonization by multiple $H$. pylori isolates while in one patient a single $H$. pylori isolate was present on antrum and corpus. Following recurrence, 4 out of 6 patients had colonization by multiple $H$. pylori isolates and 2 single H. pylori isolate on antrum and body.

\section{Antibiotic susceptibility of $\mathrm{H}$. pylori isolates}

Forty-seven $H$. pylori isolates were cultured from pretreatment biopsies. H. pylori culture was negative from both antrum and corpus in patient having a positive ${ }^{14} \mathrm{C}$-UBT at 12 month and follow up endoscopic with biopsies. Clarithromycin sensitivity was present in 30 out of $47(64 \%)$ and amoxicillin in 45 out of 47 (98\%), respectively (Table 2).

Table 2 Comparison of histology with diagnosis, bacterial colonization and antibiotic susceptibility

\begin{tabular}{|c|c|c|c|c|c|c|c|c|c|c|}
\hline & \multicolumn{3}{|c|}{ Diagnosis } & \multicolumn{2}{|c|}{ H. pylori DNA fingerprint } & \multicolumn{3}{|c|}{ Clarithromycin } & \multicolumn{2}{|c|}{ Amoxicillin } \\
\hline & Gastritis & Gastric Ulcer & Duodenal ulcer & $\begin{array}{l}\text { Same on } \\
\text { both sides }\end{array}$ & $\begin{array}{c}\text { Different on } \\
\text { both sides }\end{array}$ & Sensitive & Resistant & $\bar{P}$ & Sensitive & Resistant \\
\hline \multicolumn{11}{|l|}{ Histology } \\
\hline Grade 1 & $60(52)$ & $0(0)$ & $1(33)$ & $48(47)$ & $13(72)$ & $12(40)$ & $11(65)$ & & $22(49)$ & $1(50)$ \\
\hline Grade 2 & $51(44)$ & $1(100)$ & $2(67)$ & $49(48)$ & $5(28)$ & $18(60)$ & $5(29)$ & & $22(49)$ & $1(50)$ \\
\hline Grade 3 & $5(4)$ & $0(0)$ & $0(0)$ & $5(5)$ & $0(0)$ & $0(0)$ & $1(6)$ & & $1(2)$ & $0(0)$ \\
\hline
\end{tabular}

${ }^{*} \mathrm{n}(\%)=$ number and percentage. 


\section{Comparison of antibiotic susceptibility and H. pylori DNA fingerprint at gastric site}

H. pylori DNA fingerprints were different in antrum and corpus in $3(10 \%)$ out of 30 CLR sensitive strains compared to $10(59 \%)$ out of 17 CLR resistance H. pylori strains $(p=0.001)$.

By RFLP 18 patients had different DNA fingerprints in the antrum and corpus (Table 2). Of these 18 patients, H. pylori could be cultured from only 13 patients. Clarithromycin resistance was demonstrated by 10 out of $13 \mathrm{H}$. pylori isolates while 3 out of 13 were sensitive to CLR.

\section{Comparison of histology with diagnosis and antibiotic susceptibility}

The degree of gastric inflammation in majority of patients varied from grade 1 to 2 (Table 2). It was not significantly associated with diagnosis $(p=0.66)$ (Table 2). Grades of inflammation were equally associated with same or different $H$. pylori DNA fingerprints in antrum and corpus $(p=0.08)$ (Table 2). Eleven out of 17 (65\%) H. pylori strains demonstrating CLR resistance were associated with grade 1 inflammation $(p=0.06)$ while grade 1 to 2 inflammation were equally associated with AMX resistance $(p=$ 0.957), respectively (Table 2).

\section{Discussion and conclusion}

The results of this prospective study showed that rate of $H$. pylori recurrence after apparently successful eradication was low. Majority of our patients remained infection free at nine months and recurrence followed in about $6 \%$ at the end of one year. All the patients with recurrence had NUD while none occurred in cases with duodenal ulcer. Clarithromycin resistance was high in our H. pylori isolates and low for amoxicillin. Antibiotic susceptibility pattern was not found to be related to age and gender in this study. About $14 \%$ of our patients demonstrated colonization by multiple $H$. pylori strains. Clarithromycin resistance was associated with different $H$. pylori strains at different gastric sites as suggested by DNA fingerprinting. However, the technique used in this study looked at only one gene, and generated as few as 2 or 3 bands in some strains, making it a rather low resolution technique to declare a strain identical. Strains may show identical banding patterns in the RFLP sites in one gene, yet differ elsewhere. Furthermore, it is possible that in some subjects, the infection was eradicated, yet the subject was reinfected from family members with an identical or near-identical strain, which would be interpreted as recrudescence.

Most studies from developed countries reported less than $1 \%$ rate of $H$. pylori infection recurrence whereas relatively higher rates have been reported from developing countries [18]. True re-infection of $H$. pylori is defined as where tests for $H$. pylori infection stay negative for 12 months after eradication, and become positive again at a later stage. This is probably a rare event in developed countries. A study from the Netherlands [19] showed that at 6 years after successful triple therapy the recurrence rate of $H$. pylori infection was very low $(0.19 \%$ per patient year). Recurrence rate is higher in developing countries. In a study from Bangladesh, recrudescence, associated with nitroimidazole-based treatment, occurred in 15 of 105 patients (13\%) within the first 3 months while the annual reinfection rate was $13 \%$, based on a total follow-up of 84.7 patient years [8]. Data from India on reinfection of $H$. pylori after eradication showed that the risk is low in Indian subjects at the end of one year. The eradication rate with the four-drug regimen was $89.1 \%(41 / 46)$. Four of the 5 nonresponders eradicated $H$. pylori with the second regimen. At the end of median one year follow-up (range 9-15 months), one of the 45 patients $(2.4 \%)$ who eradicated the organism developed reinfection; none of the 46 patients who were initially $H$. pylori-negative acquired new infection [9]. In Iran, 37 patients, aged 5 to 17 years, treated with triple omeprazole based regimen the reinfection rate of H. pylori was determined during a follow up period of 12 months. After eradication therapy of H. pylori, 34 patients had a negative repeat ${ }^{13} \mathrm{C}$-UBT. Reinfection occurred in 5 (14.7\%) patients [10].

The recurrence rate of $6 \%$ in our study is similar to that reported from Chile and China $(4.2 \% / \mathrm{yr}$. and $1.08 \%$ /yr., respectively) [20,21]. It is, however, less than that reported in Korea (13\%) [22] and Bangladesh (13\%). This discrepancy might be explained by the fact that criteria to define eradication of infection, number of patients studied, and time of follow-up varied from one study to another [8,20-22]. Increased susceptibility of hosts to $H$. pylori infection and re-exposure to $H$. pylori are proposed to be the major requirements for re-infection of H. pylori $[23,24]$. Poor sanitation practices in the developing countries result in contamination of the environment with $H$. pylori, such as in drinking water, practice of eating uncooked vegetables; crowded living conditions thatl contribute to re-exposure to $H$. pylori infection and result in high prevalence of $H$. pylori infection [25-27]. Genetic factors may also play a role in re-infection of $H$. pylori infection after successful eradication. Susceptible individuals who have had $H$. pylori eradicated may be prone to re-infection with the bacterium when they are exposed to $H$. pylori-positive persons [28]. Self-prescription is also common in developing countries as medications are sold without prescriptions by pharmacies [29]. Most reports on antimicrobial therapy of H.pylori propose that antibiotic overuse selects for resistant strains as they eradicate the susceptible $H$. pylori population, and resistant survivors replace them as a resistant majority [30-33]. The 
resistance trait could be spread horizontally by plasmids to other bacterial population. Emergence of a resistance phenotype is a short-term phenomenon that takes $4-5$ years to emerge and the driving force is the indiscriminate, short-interval and frequent use of antibiotics [33-35]. Clarithromycin resistance rate was high in $H$. pylori isolates probably contributed to by use of this drug for other indications in the community and this might result in selection of stable macrolide-resistant H.pylori and indigenous microbiota [36]. Also, previously a low cure rate and a higher resistance to clarithromycin were observed among $H$. pylori positive patients with functional dyspepsia than that in peptic ulcer disease [37-39]. In an earlier study, we reported treatment failure was associated with younger mean age, cagA negativity and point mutations in $23 S$ $r R N A$ gene of $H$. pylori [40]. In conclusion, in spite of having a high prevalence of $H$. pylori there is a low incidence of recurrence of $H$. pylori infection in our population once eradication has been achieved. In view of high CLR resistance, judicious use of antibiotics should follow in general.

\section{Competing interest}

The authors declare that they have no competing interests.

\section{Authors' contributions}

SA and JY conceived and designed the study, JY did the work; SA, JY, ZAB, KM, WJ and SH coordinated the study, RA did the histopathology; JY, SA and ZA analyzed the data, JY performed the statistical analysis. JY wrote the manuscript. All authors read and approved the final manuscript.

\section{Acknowledgement}

The work was supported by research grants from Aga Khan University Research Committee to SA. We are grateful to staff members at the Juma Research Laboratory, Aga Khan University for their assistance during this work.

\section{Author details}

'Department of Medicine, Aga Khan University, Stadium Road, Karachi 74800, Pakistan. ${ }^{2}$ Department of Pathology, Aga Khan University, Stadium Road, Karachi 74800, Pakistan.

Received: 20 October 2012 Accepted: 11 February 2013 Published: 21 February 2013

\section{References}

1. Anon: NIH consensus conference. Helicobacter pylori in peptic ulcer disease. NIH consensus development panel on helicobacter pylori in peptic ulcer disease. JAMA 1994, 272:65-69.

2. Sipponen P: Gastric cancer: a long term consequence of $H$. pylori infection? Scand J Gastroenterol 1994, 29:24-27.

3. Mera R, Fontham ET, Bravo LE, Bravo JC, Piazuelo MB, Camargo MC, Correa $\mathrm{P}$ : Long term follow up of patients treated for helicobacter pylori infection. Gut 2005, 54:1536-1540.

4. Kyzekova J, Mour J: The effect of eradication therapy on histological changes in the gastric mucosa in patients with non-ulcer dyspepsia and helicobacter pylori infection. Prospective randomized intervention study. Hepatogastroenterology 1999, 46:2048-2056.

5. Larkin CJ, Watson P: Gastric corpus atrophy following eradication of helicobacter pylori. Eur J Gastroenterol Hepatol 2001, 13:377-382.

6. Niv Y: H. pylori recurrence after successful eradication. World J Gastroenterol 2008, 14:1477-1478.

7. Yakoob J, Hu G, Fan X, Zhang Z: Helicobacter pylori detection in Chinese subjects: a comparison of two common DNA fingerprinting methods. Br J Biomed Sci 2001, 58:239-243.
8. Hildebrand P, Bardhan P, Rossi L, Parvin S, Rahman A, Arefin MS, Hasan M, Ahmad MM, Glatz-Krieger K, Terracciano L, Bauerfeind P, Beglinger C, Gyr N, Khan AK: Recrudescence and reinfection with helicobacter pylori after eradication therapy in Bangladeshi adults. Gastroenterology 2001, 121:792-798.

9. Bapat MR, Abraham P, Bhandarkar PV, Phadke AY, Joshi AS: Acquisition of helicobacter pylori infection and reinfection after its eradication are uncommon in Indian adults. Indian J Gastroenterol 2000, 19:172-174.

10. Najafi M, Sobhani M, Khodadad A, Farahmand F, Motamed F: Reinfection rate after successful helicobacter pylori eradication in children. Iranian J Pediatrics 2010, 2:58-62.

11. Jafri W, Yakoob J, Abid S, Siddiqui S, Awan S, Nizami SQ: Helicobacter pylori infection in children: population-based age-specific prevalence and risk factors in a developing country. Acta Paediatr 2010, 99:279-282.

12. Morio O, Rioux-Leclercq N, Pagenault M, Corbinais S, Ramee MP, Gosselin M, Bretagne JF: Prospective evaluation of a new rapid urease test (pronto dry) for the diagnosis of helicobacter pylori infection. Gastroenterol Clin Biol 2004, 28:6-7.

13. Price AB: The Sydney System: histological division. J Gastroenterol Hepatol 1991, 6:209-222.

14. Rasool S, Abid S, Jafri W: Validity and cost comparison of 14 carbon urea breath test for diagnosis of $H$. pylori in dyspeptic patients. World J Gastroenterol 2007, 13:925-929.

15. Van Zwet AA, Thijs C, Kooistra-Smid AM, Schirm J, Snijder JAM: Sensitivity of culture compared with that of polymerase chain reaction for detection of Helicobacter pylori from antral biopsy samples. J Clin Microbiol 1993, 31:1918-1920.

16. Labigne A, Cussac V, Courcoux P: Shuttle cloning and nucleotide sequences of helicobacter pylori genes responsible for urease activity. J Bacteriol 1991, 173:1920-1931.

17. Fujimoto S, Marshall B, Blaser M: PCR-based restriction fragment length polymorphism typing of helicobacter pylori. J Clin Microbiol 1994, 32:331-334.

18. Zhang YY, Xia HH, Zhuang ZH, Zhong J: True re-infection of Helicobacter pylori after successful eradication-worldwide annual rates, risk factors and clinical implications. Aliment Pharmacol Ther 2009, 29:145-160.

19. Van der Wouden EJ, Thijs JC, van Zwet AA, Kleibeuker JH: Six-year followup after successful triple therapy for helicobacter pylori infection in patients with peptic ulcer disease. Eur J Gastroenterol Hepatol 2000, 13:1235-1239.

20. Rollan A, Giancaspero R, Fuster F, Acevedo C, Figueroa C, Hola K, Schulz M, Duarte I: The long-term reinfection rate and the course of duodenal ulcer disease after eradication of helicobacter pylori in a developing country. Am J Gastroenterol 2000, 95:50-56.

21. Mitchell HM, Hu P, Chi Y, Chen MH, Li YY, Hazell SL: A low rate of reinfection following effective therapy against helicobacter pylori in a developing nation (china). Gastroenterology 1998, 114:256-260.

22. Kim N, Lim SH, Lee KH, Jung HC, Song IS, Kim CY: Helicobacter pylori reinfection rate and duodenal ulcer recurrence in Korea. $J$ Clin Gastroenterol 1998, 27:321-326.

23. Xia HH, Talley NJ: Natural acquisition and spontaneous elimination of helicobacter pylori infection. Am J Gastroenterol 1997, 92:1780-1787.

24. Xia HH, Talley NJ, Keane CT, O'Morain CA: Recurrence of helicobacter pylori infection after successful eradication: nature, possible causes and potential preventive strategies. Digest Dis Sci 1997, 42:1821-1834.

25. Hulten K, Han SW, Enroth H, Klein PD, Opekun AR, Gilman RH, Evans DG, Engstrand L, Graham DY, El-Zaatari FA: Helicobacter pylori in the drinking water in Peru. Gastroenterology 1996, 110:1031-1035.

26. Klein PD, Graham DY, Gaillour A, Opekun AR, Smith EO: Water source as risk factor of helicobacter pylori infection in Peruvian children. Lancet 1991, 337:1503-1506.

27. Hopkins RJ, Vial PA, Ferreccio C, Ovalle J, Prado P, Sotomayor V, Russell RG, Wasserman SS, Morris JG Jr: Seroprevalence of helicobacter pylori in Chile: vegetable s may serve as one route of transmission. J Infect Dis 1993, 168:222-226.

28. Azuma T, Konishi J, Tanaka Y, Hirai M, Ito S, Kato T, Kohli Y: Contribution of HLA-DQA gene to host's response against helicobacter pylori. Lancet 1994, 343:542-543.

29. Sturm AW, van der Pol R, Smits AJ, van Hellemondt FM, Mouton SW, Jamil B, Minai AM, Sampers GH: Over-the-counter availability of antimicrobial agents, self-medication and patterns of resistance in Karachi, Pakistan. J Antimicrob Chemother 1997, 39:543-547. 
30. Yakoob J, Jafri W, Abid S, Jafri N, Abbas Z, Hamid S, Islam M, Anis K, Shah $\mathrm{HA}$, Shaikh $\mathrm{H}$ : Role of rapid urease test and histopathology in the diagnosis of helicobacter pylori infection in a developing country. BMC Gastroenterol 2005, 5:38.

31. Sharara Al, Chedid M, Araj GF, Barada KA, Mourad FH: Prevalence of Helicobacter pylori resistance to metronidazole, clarithromycin, amoxycillin and tetracycline in Lebanon. Int J Antimicrob Agents 2002, 19:155-158.

32. Wu H, Shi XD, Wang HT, Liu JX: Resistance of helicobacter pylori to metronidazole, tetracycline and amoxycillin. J Antimicrob Chemother 2000 46:121-123.

33. Bennett PM: Plasmid encoded antibiotic resistance: acquisition and transfer of antibiotic resistance genes in bacteria. Br J Pharmacol 2008 153:S347-S357.

34. Mégraud F: Resistance of helicobacter pylori to antibiotics. Aliment Pharmacol Ther 1997, 11(Suppl 1):43-53.

35. Aguilar GR, Ayala G, Fierros-Zárate G: Helicobacter pylori: recent advances in the study of its pathogenicity and prevention. Salud Publica Mex 2001, 43:237-247

36. Sjölund M, Tano E, Blaser MJ, Andersson DI, Engstrand L: Persistence of resistant staphylococcus epidermidis after single course of clarithromycin. Emerg Infect Dis 2005, 11:1389-1393.

37. Broutet N, Tchamgoué S, Pereira E, Lamouliatte H, Salamon R, Mégraud F: Risk factors for failure of helicobacter pylori therapy results of an individual data analysis of 2751 patients. Aliment Pharmacol Ther 2003, 17:99-109.

38. Graham DY: Antibiotic resistance in helicobacter pylori: implications for therapy. Gastroenterology 1998, 115:1272-1277.

39. Houben MH, van de Beek D, Hensen EF, de Craen AJ, Rauws EA, Tytgat GN: A systematic review of helicobacter pylori eradication therapy: the impact of antimicrobial resistance on eradication rates. Aliment Pharmacol Ther 1999, 13:1047-1055.

40. Yakoob J, Jafri W, Abbas Z, Abid S, Naz S, Khan R, Khalid A: Risk factors associated with helicobacter pylori infection treatment failure in a high prevalence area. Epidemiol Infect 2011, 139:581-590.

doi:10.1186/1471-230X-13-33

Cite this article as: Yakoob et al:: Low rate of recurrence of Helicobacter Pylori infection in spite of high clarithromycin resistance in Pakistan. BMC Gastroenterology 2013 13:33.

\section{Submit your next manuscript to BioMed Central and take full advantage of:}

- Convenient online submission

- Thorough peer review

- No space constraints or color figure charges

- Immediate publication on acceptance

- Inclusion in PubMed, CAS, Scopus and Google Scholar

- Research which is freely available for redistribution 